\title{
Determination of Work Index of Filin Kokuwa Gold Deposit in Toro Local Government, Bauchi State Nigeria
}

\author{
D. M. Bwala ${ }^{\mathrm{a}, \mathrm{b}}$, F. Abdulfattah ${ }^{\mathrm{b}, *}$, O. O. Alabi ${ }^{\mathrm{a}}$, B. O. Adewuyi ${ }^{\mathrm{a}}$ \\ ${ }^{a}$ Federal University of Technology, Akure, Ondo State, NIGERIA. \\ ${ }^{b}$ Nigerian Institute of Mining and Geosciences, Jos, Plateau State, NIGERIA.
}

\begin{abstract}
This report shows the work index of Filin Kokuwa Gold ore sample in Bauchi State, Nigeria. The "reference sample (granites)" were sourced from outcrops of granites around Toro town. The samples were crushed, ground, and pulverized using appropriate laboratory milling machine. $80 \%$ passing size for the gold ore and granites samples were obtained at $100 \mu \mathrm{m}$ sieve size for the ball mill feeds and products respectively. The work indexes of reference samples i.e. granites were used to calculate the work index of the Filin Kokuwa gold ore sample. The values of $13.277 \mathrm{kWh} /$ ton and $15.192 \mathrm{kWh} /$ ton were obtained respectively for the two different reference granites samples used and $14.21 \mathrm{kWh} /$ ton as their average which is the value of the work index of the Filin Kokuwa gold ore deposit. The energy required for grinding the ore was found to be $3.581 \mathrm{~kW}$.
\end{abstract}

Keywords: work index, gold ore, granites, comminution, modified bond's

\section{INTRODUCTION}

Nigeria is one of the most endowed countries in the world with a lot of minerals reserve. The vast reserve of mineral resources in Nigeria are sufficient enough without need for raw materials importation. Minerals that are known to exist in commercial quantities in Nigeria include iron ore, cassiterite, columbite, tantalite, titanium, rutile, feldspar, gold, limestone, lead, zinc, uranium, quartz and mineral fuel like coal etc [1,2]. These industrial minerals cut across the entire states of the country.

Four gold fields, encompassing the main producing area, can be defined in the western province basement; Ilesha-Egbe, Minna BirninGwari, Sokoto, and Yelwa [3]. All are generally associated with the schist belts although gold-quartz veins also occur in gneisses (e.g. Malele, Diko, and Iperindo gold mines). The Iperindo mineralization comprises a series of auriferous quartz-carbonate veins localized by a subsidiary fault within biotite gneiss and mica schist, presently defined by subparallel old workings extending overall for about 9 meters in the NNE direction. Gold quartz veins are generally conformable with the North-South to North North East-South South West structural grain of basement rocks. The schist belts of Nigeria are hosts to many mineral deposits.

* Corresponding author (Tel: +234(0) 813758 3918)

Email addresses: recca_dan@yahoo.com (D. M. Bwala), fa1700001.mme@buk.edu.ng (F. Abdulfattah), oladunni69alabi@yahoo.com (O. O. Alabi), (B. O. Adewuyi)
Precambrian rocks within and around Maru Schist belt host some quartz veins that are gold bearing. The gold deposits were heavily mined during the colonial era approximately before 1960 and after that period by artisanal miners. General descriptive information on gold mineralization in Maru schist belt has been documented [4$6]$. Gold occurs primarily in quartz veins and as placers in soil (eluvial) and stream sediments (alluvial). The quartz veins containing gold occur in association with metamorphosed rocks ranging in composition from semi-pelitic to pelitic and mafic. Primary gold mineralization produced chemical signature in the overburden and surrounding soil probably through weathering processes. Weathering processes provide samples (soils and stream sediments) that yield data on local hidden mineralization or on the potential existence of major or minor mineralization in a wide region. The residual soil is the geochemical sample that is often used to detect the location of hidden mineralization once a zone of economic interest is localized [7].

Gold production in Nigeria is believed to have started in 1913 and got to its peak from 1933-1943 [8]. Gold occurs with pyrite, pyrrhotite and minor chalcopyrite, galena, sphalerite, magnetite and ilmenite $[9,10]$.

\subsection{Theoretical Consideration for Com- minution Process (Work Index)}

The modified Bond's equation called Berry and Bruce comparative Bond's equation is what was used to ascertain the work index of the ore. Work 
index is the comminution parameter which expresses the resistance of material to crushing and grinding; it is the kilowatt hour per short-ton required to reduce the material from theoretically infinite feed size to $80 \%$ passing $100 \mu \mathrm{m}[2,11]$. Table 1 gives the work index of some minerals ores samples.

Table 1: Work index of some minerals ores samples.

\begin{tabular}{llll}
\hline Material & Work index & Material & Work index \\
\hline Barite & $4.28-6.24$ & Fluorspar & $2.98-9.76$ \\
Bauxite & $2.38-9.45$ & Granite & $2.68-15.13$ \\
Coal & $1.63-11.37$ & Graphite & $1.75-45.03$ \\
Dolomite & $2.82-11.27$ & Limestone & $2.69-11.61$ \\
Emery & $3.48-58.18$ & Quartzite & $2.71-17.4$ \\
Columbite & $3.94-10.81$ & Titanium ore & $4.23-11.88$ \\
Tantalite & $3.6-11.90$ & Silica sand & $2.65-16.46$ \\
Gold Ore & $3-42$ & Silver Ore & $13-22$ \\
\hline \multicolumn{5}{c}{ Sources: $[1,2,11-13]$} \\
\hline
\end{tabular}

The work index of an ore can be determined by using Berry and Bruce method developed in (1966) also known as modified Bond's equation, which is a comparative method of determining ore grindability. The method requires the use of a reference sample of known work index. Work index is the energy required in $\mathrm{kWh} /$ short-ton to reduce a given material from theoretically infinite size to $80 \%$ passing size, 100 microns $[2,14]$. The reference ore is ground for a certain time $(\mathrm{T})$ in a laboratory tumbling mill and an identical weight of the test ore is then ground for the same time. Since the power input to the mill is constant $(\mathrm{P})$, the energy input Eq. (1) is the same for both reference and test ore. If $r$ is the reference ore and $t$ the ore under test, then we can determine it from Bond's Equation which is written as [11]:

$$
\begin{gathered}
(E=P \times T) \\
W=10 \times W i\left(\frac{1}{\sqrt{P_{80}}}-\frac{1}{\sqrt{F_{80}}}\right) \\
W r=W t=W i_{r}\left[\frac{10}{\sqrt{P_{80 r}}}-\frac{10}{\sqrt{F_{80 r}}}\right] \\
=W i_{t}\left[\frac{10}{\sqrt{P_{80 t}}}-\frac{10}{\sqrt{F_{80 t}}}\right]
\end{gathered}
$$

therefore

$$
W i_{t}=W i_{r} \frac{\left[\frac{10}{\sqrt{P_{80 r}}}-\frac{10}{\sqrt{F_{80 r}}}\right]}{\left[\frac{10}{\sqrt{P_{80 t}}}-\frac{10}{\sqrt{F_{80 t}}}\right]}
$$

where $W r=$ Work input of reference sample; $W t=$ Work input of test ore; $W i_{r}=$ Work index of reference sample; $W i_{t}=$ Work index of test ore $P_{80 r}=$ $80 \%$ of discharge reference sample passes; $P_{80 t}=$ $80 \%$ of discharged test ore passes; $F_{80 r}=80 \%$ of feed reference sample passes; $F_{80 t}=80 \%$ of feed test ore passes.

\subsection{Literature Review}

The work index expresses the resistance of the material to grinding. It represents the kilowatt hours per tonne required to reduce the material from theoretically infinite feed size to 80 percent passing $100 \mu \mathrm{m}$ [15]. Bond devised several methods for predicting ball-mill and rod-mill energy requirements and provided an accurate measure of ore grindability [16]. The standard Bond test requires constant screening out of undersized material in a closed-circuit operation. The standard Bond experiment has been applied for the determination of Bond work indices of several minerals by different researchers [17-19].

Egbe et al. [20] adopted Bond's equation to determine the work index of Baban-Tsauni (Nigeria) Lead-Gold ore. The bond work index of Baban-Tsauni lead-gold ore was found to be $11.52 \mathrm{~kW} . \mathrm{h} / \mathrm{ton}$. Oladunni et al. [2] worked on Gyel-Bukuru columbite work index using modified Bond's equation, it was discovered that Gyel-Bukuru has an average work index of 3.07 $\mathrm{kW} . \mathrm{h} / \mathrm{ton}$. Adeoti et al. [21] determined the work index of Saman-Burkono graphite using modified bond's method and found the work index to be $11.047 \mathrm{kWh} / \mathrm{short}$ ton. In the same vain, Adetula et al. [22] using Modified Bond's Index Equation to determine the work index of Iperindo lode gold deposit. The work index was determined to be 11.92 $\mathrm{kW} . \mathrm{h} / \mathrm{ton}$. This research is aimed at determining the work index of Filin Kokuwa Gold ore, using granite with known work index as reference sample, through modified Bond's equation.

\section{MATERIALS AND METHOD}

\subsection{Materials}

Fifty kilograms $(50 \mathrm{~kg})$ of the alluvial ore sample used in this research was obtained from Filin Kokuwa Gold deposit mined at various pits 7 meters apart. This location is about seven (7) kilometres off Bauchi-Jos express road. The granite samples used as reference samples were sourced from granite outcrops around Toro Local Government Area.

\subsection{Method}

The sample of the test ore (Gold sample) was crushed manually with a sledge hammer to provide required size acceptable as feed to the Denver laboratory jaw crusher. The sample was crushed and ground, part of the ground sample was weighed for sieve analysis. The modified Bond's method of determining the net-work index of ore involves use of reference sample of which grindability is known. The procedure is as follows;

1. $100 \mathrm{~g}$ each of samples of the ore under test and the reference ore were crushed and ground in the laboratory mill machine for an hour,

2. The samples of test ore and reference sample were taken and sized by sieving into a number of size fractions using the automatic sieve shaker for 15 minutes. 
Table 2: Sieve analysis of crude sample of Filin Kokuwa gold ore (feed to the ball mill).

\begin{tabular}{lcccc}
\hline $\begin{array}{l}\text { Sieve Size } \\
(\mu \mathbf{m})\end{array}$ & Weight Retained & $\%$ Weight Retained Cummulative $\%$ Retained Cummulative $\%$ Passing \\
\hline+1000 & & & & 9.281 \\
$-1000+600$ & 9.28 & 9.281 & 15.212 & 90.719 \\
$-600+500$ & 8.93 & 5.931 & 23.543 & 76.788 \\
$-500+350$ & 17 & 17.001 & 40.544 & 59.456 \\
$-350+210$ & 13.43 & 13.431 & 53.975 & 46.025 \\
$-210+180$ & 12.98 & 12.981 & 66.956 & 33.044 \\
$-180+125$ & 2.99 & 2.99 & 69.946 & 30.054 \\
$-125+90$ & 10.7 & 10.701 & 80.647 & 19.353 \\
$-90+63$ & 4.01 & 4.011 & 100 & 15.342 \\
-63 & 15.34 & 15.342 & & \\
Total & 99.99 & 100 &
\end{tabular}

Table 3: Sieve analysis of granite 1 sample feed to the ball mill.

\begin{tabular}{lcccc}
\hline $\begin{array}{l}\text { Sieve Size } \\
(\mu \mathbf{m})\end{array}$ & Weight Retained & \% Weight Retained Cummulative \% Retained Cummulative \% Passing \\
\hline+1000 & 12.48 & 12.514 & 12.514 & 87.486 \\
$-1000+600$ & 8.35 & 8.373 & 20.887 & 79.113 \\
$-600+500$ & 9.65 & 9.676 & 30.563 & 69.437 \\
$-500+350$ & 17.26 & 17.307 & 57.87 & 52.13 \\
$-350+210$ & 11.78 & 11.812 & 59.682 & 40.318 \\
$-210+180$ & 11.88 & 11.912 & 74.594 & 28.406 \\
$-180+125$ & 2.76 & 2.767 & 83.315 & 25.639 \\
$-125+90$ & 8.93 & 8.954 & 86.764 & 16.685 \\
$-90+63$ & 3.44 & 3.449 & & 13.236 \\
-6313.2 & 13.236 & 100 & \\
Total & 99.73 & 100 & & \\
\hline
\end{tabular}

3. Each size fractions of the test ore and the reference sample were weighed and the value noted as "feed".

4. The "feed" test ore and reference sample were each gathered together and introduced into the Laboratory ball milling machine and ground for 1 hour.

5. The test ore and the reference sample from the laboratory ball mill machine were sized and each sieve fraction was weighed and the value noted as the discharge or product [9].

6. Sieve analysis was done, the ground samples were sieved into the following sieve size fractions; $+1000 \mu \mathrm{m},-1000+600 \mu \mathrm{m},-600+500$ $\mu \mathrm{m},-500+350 \mu \mathrm{m},-350+210 \mu \mathrm{m},-210+180$ $\mu \mathrm{m},-180+125 \mu \mathrm{m},-125+90 \mu \mathrm{m},-90+63 \mu \mathrm{m}$, $-63 \mu \mathrm{m}$ using Denver automatic sieve shaker for 15 minutes.

\section{RESULTS AND DISCUSSION}

\subsection{Results}

3.1.1. Test Ore (Filin Kokuwa Gold)/References (Granites 1 and 2) samples as Feeds to the Ball Mill

Table 2 gives the sieve analysis result of the feed to ball mill of test ore (gold ore).

Calculation using the values in Table 2.

If $710 \mu \mathrm{m}=84.788$

Then X $=80 \%$ Using Gaudin Schumann Expression

$$
\begin{gathered}
P(X)=100[X / K]^{a} \\
a=\frac{\left[\log P\left(X_{2}\right)-P\left(X_{1}\right)\right]}{\log \left(X_{2}\right)-\left(X_{1}\right)} \\
\text { Size }_{2}=\frac{\left(\text { Percentage passing size }_{2}\right)^{2}}{\left(\text { Percentage passing size }_{1}\right)^{2}} \times \text { size }_{1} \\
X \mu m=\left(\frac{\frac{80}{100}}{\frac{84.788}{100}}\right)^{2} \times 710=631.367 \mu m \text { at } 80 \%
\end{gathered}
$$

Table 3 gives the sieve analysis of the feed of reference sample 1 to the ball mill. Using data from Table 3

If $710 \mu \mathrm{m}=79.113$

The $X \mu \mathrm{m}=80 \%$

$$
X \mu m=\left(\frac{\frac{80}{100}}{\frac{79.113}{100}}\right)^{2} \times 710=726.249 \mu m \text { at } 80 \%
$$

Calculations using data from Table 4 If $710 \mu \mathrm{m}=81.944$

Then 
Hence;

$$
X \mu m=\left(\frac{\frac{80}{100}}{\frac{81.944}{100}}\right)^{2} \times 710=677.440 \mu m \text { at } 80 \%
$$

\subsubsection{Test Ore (Filin Kokuwa Gold Ore)/References Sample Discharges as Product from the Ball Mill}

Table 5: gives the sieve analysis of the product of test material in the ball mill (Filin Kokuwa Gold) product from ball mill.

Calculations using data from Table 5 If $210 \mu \mathrm{m}$ $=75.271$

$$
X \mu m=\left(\frac{\frac{80}{100}}{\frac{75.271}{100}}\right)^{2} \times 210=237.090 \mu m \text { at } 80 \%
$$

Table 6: gives the sieve analysis of the product of test material from the ball mill (of Granite 1).

Calculations using data from Table 6

If $350 \mu \mathrm{m}=87.946$

$$
X \mu m=\left(\frac{\frac{80}{100}}{\frac{87.946}{100}}\right)^{2} \times 350=289.256 \mu m \text { at } 80 \%
$$

Table 7: gives the sieve analysis of the product of reference sample from the ball mill (granite 2).

Calculations using data from Table 7

$$
\begin{aligned}
& \text { If } 210 \mu \mathrm{m}=77.068 \\
& \qquad X \mu m=\left(\frac{\frac{80}{100}}{\frac{77.068}{100}}\right)^{2} \times 210=226.095 \mu \mathrm{m} \text { at } 80 \%
\end{aligned}
$$

Combining Bond's Eq. (2) and (3), we have;

$$
W i_{t}=W i_{r} \frac{\left[\frac{10}{\sqrt{P_{80 r}}}-\frac{10}{\sqrt{F_{80 r}}}\right]}{\left[\frac{10}{\sqrt{P_{80 t}}}-\frac{10}{\sqrt{F_{80 t}}}\right]}
$$

where, $W i_{r}=$ work index of the reference sample; $W i_{t}=$ work index of test ore; $P_{r}=$ the diameter of the reference sample product, $80 \%$ of which passes through $100 \mu \mathrm{m}$ aperture; $P_{t}=$ the diameter of the test ore product, $80 \%$ of which passes through $100 \mu \mathrm{m}$ aperture; $F_{r}=$ the diameter of the reference sample feed, $80 \%$ of which passes through $100 \mu \mathrm{m}$ aperture; $F_{t}=$ the diameter of the test ore feed, $80 \%$ of which passes through $100 \mu \mathrm{m}$ aperture; $W_{r}=$ work input in kilowatt hour/short ton for reference sample and; $W_{t}=$ work input in kilowatt hour/short ton for test ore.

Therefore, using granite 1 as the reference sample and Filin Kokuwa Gold ore as the test ore

$P_{r}=289.256 \mu \mathrm{m} F_{r}=726.249 \mu \mathrm{m} P_{t}=237.09 \mu \mathrm{m}$ $F_{t}=631.367 \mu \mathrm{m} W_{i r}=15.13$ (granite work index value [11]).

$$
W_{i r}=15.13 \frac{(\sqrt[10]{289.256}-\sqrt[10]{726.249})}{(\sqrt[10]{289.256}-\sqrt[10]{726.249})}
$$

Also, by using granite 2 as the reference sample and Filin Kokuwa Gold ore as the test ore $P_{r}=$ $226.095 \mu \mathrm{m} F_{r}=677.44 \mu \mathrm{m} P_{t}=237.09 \mu \mathrm{m} F_{r}=$ $631.367 \mu \mathrm{m} W_{i r}=13.57$ (granite work index value [11]).

Therefore:

$$
W_{i r 2}=13.57 \frac{(\sqrt[10]{226.095}-\sqrt[10]{677.44})}{(\sqrt[10]{237.09}-\sqrt[10]{631.367})}
$$

From the above, the Average work index = $W_{t}=\left(W_{i t 1}+W_{i t 2} / 2=(13.227+15.192) / 2=\right.$ $14.21 \mathrm{~kW} . \mathrm{h} /$ ton

While, Energy used for grinding Filin Kokuwa Gold ore is;

$$
\begin{aligned}
W & =10 \times W_{t}\left(\frac{1}{\sqrt{P_{80}}}-\frac{1}{\sqrt{F_{80}}}\right) \\
& =10 \times 14.21\left(\frac{1}{\sqrt{237}}-\frac{1}{\sqrt{631.367}}\right)=3.581 \mathrm{~kW}
\end{aligned}
$$

\subsection{Discussion}

Tables $2-7$ give the results of the particle sieve size analysis of the test ores (Gold Ore) and reference sample (Granite). The $80 \%$ passing for both the feeds and products sieves size fractions for the Filin Kokuwa gold ores and the references (granite) samples. The $80 \%$ passing particle size fraction for both feed and product of the as-received Filin Kokuwa Gold ore sample was found to be $631.367 \mu \mathrm{m}$ and $237.09 \mu \mathrm{m}$ respectively while the work index of the as received Filin Kokuwa Gold ore sample was computed to be $14.21 \mathrm{kWh} /$ ton on the average which when compared to the work index of exiting gold ores in literatures, the result obtained lies favourably within the work indexes of $3-42 \mathrm{kWh} /$ ton for gold ores as sighted in the literatures $[1,11,23]$. The $14.21 \mathrm{kWh} /$ ton work index obtained for the Filin Kokuwa gold ore sample means that $14.21 \mathrm{kWh}$ of energy is required to reduce one ton of the as-received Filin Kokuwa gold ore sample from $80 \%$ passing size of $631.367 \mu \mathrm{m}$ to $80 \%$ passing size of $237.09 \mu \mathrm{m}$. Furthermore, using the Standard Denver grindability test curves the Filin Kokuwa gold ore is classified as a medium texture type ore, the value obtained compares well with range for standard work index for gold which is between 3 - 42kW.h/ton [13, 24], while the energy utilized in grinding of the Filin Kokuwa Gold ore calculated to be $3.581 \mathrm{~kW}$.

\section{CONCLUSION}

In conclusion the work index of Filin Kokuwa gold ore sample from Toro Local Government Area of Bauchi state, Nigeria has been determined and found to be $14.21 \mathrm{kWh} /$ ton on average and energy utilized to be $3.581 \mathrm{~kW}$. These parameters are significant in the design of a process route for the beneficiation of the Filin Kokuwa gold ore sample. 
Table 4: Sieve analysis of the granite 2 sample feed to the ball mill.

\begin{tabular}{|c|c|c|c|c|}
\hline $\begin{array}{l}\text { Sieve Size } \\
(\mu \mathrm{m})\end{array}$ & Weight Retained & $\%$ Weight Retained & Cummulative $\%$ Retained & Cummulative $\%$ Passing \\
\hline+1000 & 10.38 & 10.395 & 10.395 & 89.605 \\
\hline$-1000+600$ & 7.65 & 7.661 & 18.056 & 81.944 \\
\hline$-600+500$ & 8.67 & 8.682 & 26.738 & 73.262 \\
\hline$-500+350$ & 16.64 & 16.663 & 43.401 & 56.599 \\
\hline$-350+210$ & 11.66 & 11.676 & 55.077 & 44.923 \\
\hline$-210+180$ & 11.64 & 11.656 & 66.733 & 33.267 \\
\hline$-180+125$ & 2.88 & 2.884 & 69.617 & 30.383 \\
\hline$-125+90$ & 9.94 & 9.954 & 79.571 & 20.429 \\
\hline$-90+63$ & 3.52 & 3.525 & 83.096 & 16.904 \\
\hline-63 & 16.88 & 16.904 & 100 & \\
\hline Total & 99.86 & & & \\
\hline
\end{tabular}

Table 5: Sieve analysis for sample of Filin Kokuwa gold ore (product of test gold) from ball mill .

\begin{tabular}{lcccc}
\hline $\begin{array}{l}\text { Sieve Size } \\
(\mu \mathbf{m})\end{array}$ & Weight Retained & \% Weight Retained Cummulative $\%$ Retained Cummulative $\%$ Passing \\
\hline+1000 & 0.27 & 0.272 & 0.272 & 99.728 \\
$-1000+600$ & 0.26 & 0.262 & 0.534 & 99.466 \\
$-600+500$ & 1.03 & 1.037 & 1.571 & 98.429 \\
$-500+350$ & 9.03 & 9.092 & 10.663 & 89.337 \\
$-350+210$ & 13.97 & 14.066 & 24.729 & 75.271 \\
$-210+180$ & 17.37 & 17.489 & 42.218 & 57.782 \\
$-180+125$ & 3.09 & 3.111 & 45.329 & 54.671 \\
$-125+90$ & 18.4 & 18.526 & 77.044 & 36.145 \\
$-90+63$ & 13.1 & 13.189 & 100 & 22.956 \\
-63 & 22.8 & 22.956 & & \\
Total & 99.32 & 100 & & \\
\hline
\end{tabular}

Table 6: Sieve analysis of granite 1 product from ball mill.

\begin{tabular}{lcccc}
\hline $\begin{array}{l}\text { Sieve Size } \\
(\mu \mathbf{m})\end{array}$ & Weight Retained & \multicolumn{3}{l}{ \%eight Retained Cummulative \% Retained Cummulative \% Passing } \\
\hline+1000 & 0.19 & 0.191 & 0.191 & 99.809 \\
$-1000+600$ & 0.29 & 0.292 & 0.483 & 99.517 \\
$-600+500$ & 2.02 & 2.034 & 2.517 & 97.483 \\
$-500+350$ & 9.47 & 9.537 & 12.054 & 87.946 \\
$-350+210$ & 14.26 & 14.361 & 26.415 & 73.585 \\
$-210+180$ & 16.24 & 16.354 & 42.769 & 53.231 \\
$-180+125$ & 4.11 & 4.139 & 46.908 & 37.765 \\
$-125+90$ & 15.22 & 15.327 & 62.235 & 26.113 \\
$-90+63$ & 11.57 & 11.652 & 13.887 & \\
-63 & 25.93 & 26.113 & & \\
Total & 99.3 & &
\end{tabular}

Table 7: Sieve analysis of reference sample 2 product from ball mill.

\begin{tabular}{|c|c|c|c|c|}
\hline $\begin{array}{l}\text { Sieve Size } \\
(\mu \mathrm{m})\end{array}$ & Weight Retained & $\%$ Weight Retained & Cummulative $\%$ Retained & Cummulative $\%$ Passing \\
\hline+1000 & 0.3 & 0.302 & 0.302 & 99.698 \\
\hline$-1000+600$ & 0.12 & 0.121 & 0.423 & 99.577 \\
\hline$-600+500$ & 1.06 & 1.068 & 1.491 & 98.509 \\
\hline$-500+350$ & 9.02 & 9.088 & 10.579 & 89.421 \\
\hline$-350+210$ & 12.26 & 12.353 & 22.932 & 77.068 \\
\hline$-210+180$ & 16.54 & 16.665 & 39.597 & 60.403 \\
\hline$-180+125$ & 3.31 & 3.335 & 42.932 & 57.068 \\
\hline$-125+90$ & 16.2 & 16.322 & 59.254 & 40.746 \\
\hline$-90+63$ & 11.4 & 11.486 & 70.74 & 29.26 \\
\hline-63 & 29.04 & 29.26 & 100 & \\
\hline Total & 99.25 & & & \\
\hline
\end{tabular}




\section{References}

[1] D. Thomas, F. Asuke, and S. Yaro, "Determination of Some Conceptual Mineral Processing Parameters of Soba-Wanka Pyrochlore-Col Tan Mineral Ore Deposit," in Nigeria Engineering Conference, 2014, pp. 32-41.

[2] O. Alabi, S. Yaro, G. Dungka, F. Asuke, and E. Dauda, "Determination of Work Index of GyelBukuru Columbite Ore in Plateau State, Nigeria." Scientific Research Publishing, Journal of Minerals and Materials Characterization and Engineering, vol. 3, pp. 194-203, 2015.

[3] M. Woakes and B. Bafor, "Primary gold mineralization in Nigeria," Journal of African Earth Sciences, vol. 6, pp. 655-661, 1984

[4] J. Truswell and R. Cope, "The Geology of Parts of Niger and Zaria Provinces, Northern Nigeria," Geological Survey Nigeria Bulletin, 1963, 29.

[5] M. Woakes and B. E. Bafor, "Primary gold mineralization in Nigeria," in Geological Society of Zimbabwe Special Publication, R. Foster, Ed., no. 1, Balkema, Rotterdam, The Netherlands, 1983.

[6] K. D'Souza, U. Danbatta, and P. Newall, "Comprehensive solid minerals resource survey and assessment," 2005, tech. Rep.

[7] F. Siegel, Applied Geochemistry. New Jersey, NJ, USA: John Wiley \& Sons, 1974.

[8] MMSD, "Comprehensive solid minerals resource survey and assessment," 2010.

[9] A. Manu, Y. Wumasi, and T. Coleman, "Application of Remote Sensing and GIS Technologies to Assess the Impact of Surface Mining at Tarkwa, Ghana." 2004.

[10] G. Hilson "The socio-economic impacts of artisanal and small scale mining in developing countries," Taylor \& Francis, vol. 38, pp. 2-24, 2006.

[11] B. Wills and T. Napier-Mum, Mineral Processing Technology, 7th ed. Amsterdam: Elsevier Science \& Technology Books, 2006.

[12] 2012, 4-9.

[13] (2020, October) Table of bond work index by minerals. [Online]. Available: https://www.911metallurgist.com/ blog/table-of-bond-work-index-by-minerals

[14] (2020, October) Summary and determination of the bond work index using an ordinary laboratory batch ball mill. [Online]. Available: OneMine.com

[15] B. Wills and T. W. Napier-Munn, Mineral Processing Technology-An Introduction to the Practical Aspects of Ore Treatment and Mineral Recovery, 7th ed. Amsterdam: Elsevier Science and Technology Books, 2006.

[16] A. Gupta and D. Yan, Mineral Processing Design and Operation- An Introduction. Amsterdam: Elsevier, 2006.

[17] J. Levin, "Indicators of grindability and grinding efficiency," Journal of South Africa Institute Minerals and Metallurgy, vol. 92, no. 10, pp. 283-290, 1992.

[18] V. Deniz, "Relationships between bond's grindability (gbg) and breakage parameters of grinding kinetic on limestone," in Proceedings of 18th International Mining Congress and Exhibition of Turkey-IMCET, 2003, pp. 451-456.

[19] A. Doll and D. Barratt, "Grinding: Why so many tests?" in 43rd Annual Meeting of the, Canadian Mineral Processors, Ottawa, Ontario, Canada, January 2011.

[20] E. Egbe, E. Mudiare, O. Abubakre, and M. Ogunbajo, "Determination of the Bond's Work Index of BabanTsauni (Nigeria) Lead-Gold Ore," European Scientific Journal, vol. 9, no. 12, April 2013.

[21] Y. Adetula, O. B., O. Álabi, A. John, and A. A., "Determination of Work Index for Iperindo Lode Gold Deposit at Ilesha Goldfield Osun State, Nigeria Using Modified Bond Index," American Journal of Materials Synthesis and Processing, vol. 4, no. 1, pp. 37-42, 2013.

[22] M. Adeoti, O. Dahunsi, O. Awopetu, F. Aramide, O. Alabi, O. Johnson, and A. Abdul-Kareem, "Determination of Work Index of Graphite from Saman-Burkono (Nigeria) Using Modified Bond's Method," Nigerian Journal of Technology (NIJOTECH), vol. 38, no. 3, pp. 609-613, July 2019.

[23] Particle Characterization, Mineral Processing Handbook. American Institute of Mining and Metallurgical, 1985 , vol. 1 , no. $142-156$.
[24] G. Mathur, "Terminal report," Central Metallurgical Research and Development Institute, Tech. Rep. 2, 1985. 